\title{
Teacher's Strategies to Overcome Students' Difficulties When Implementing Time Token Arends Method in Learning Speaking English
}

\author{
Nailul Fauziyah*, Nurul Fitria \\ Darul 'Ulum (UNIPDU) Jombang, Indonesia \\ *Corresponding Author \\ Email: fauziyahnailul.unipdu@gmail.com
}

English Education, Faculty of Teacher Training and Education, Universitas Pesantren Tinggi

$\begin{array}{llll}\text { Received: } & \text { Revised: } & \text { Accepted: } & \text { Published: } \\ \text { 29 June 2021 } & \text { 2 July 2021 } & \text { 27 July 2020 } & \text { 31 July 2021 }\end{array}$

\begin{abstract}
This study concerned with the teacher's strategies in learning speaking English. This research is focused on how the teacher overcomes the students' weaknesses in learning speaking English when implementing Time Token Arends method. By using a descriptive qualitative research within a teacher of MA Al-Bairuny as a subject of its research found that: (1) the student had difficulty in inhibition such as: difficulty in starting to speak because of being worried of making mistakes, difficulty in answering the question from the teacher, and they felt nervous and shy to speak in front of the class. (1) The teacher used "Look in the Face" strategy to overcome the difficulties; (2) the teacher used "Communication" strategies to overcome the students' difficulties in nothing to say, such as: students had no idea to speak, student got difficulty to express what he wanted to speak, and student had no bravery to express their thought; (3) the teacher used "Interdependence" strategies to overcome the students' difficulties in un-event participant; (4) the teacher used "Responsibility" strategies to overcome students' difficulties in mother tongue used, such as: students felt easier for communication each other using Java Language, so they ignored the teacher's instruction for speaking English; (5) then, after the learning process, teacher made a schedule for this group to evaluate their teamwork process in order to give them motivation and evaluation. Thus, the students' improvement on their speaking skill has been the aim of the research.
\end{abstract}

Keywords: Speaking; Time Token Arends Method; Students' difficulties; Teacher's Strategies.

\section{INTRODUCTION}

As Brown (2001) says that the important aspect in language learning is speaking for a productive skill. Hence, by speaking, language learners can deliver information and ideas, express opinion and feeling, share experiences, and maintain social relationship by communicating with others (Brown, 2001). Accordingly, the teacher must prepare the strategy and method before the learning process. Thus, the teacher should have good way to help students and how to teach them well in learning speaking. Though, there are many methods to make learners enjoyed in learning speaking English, the teacher at the first grade of science in MA AL-Bairuny implements Time Token Arends in learning speaking. The teacher gets believing that Time Token Arends can help students easy to learn speaking English. Istarani (cited in Sukmayati, 2014) states that Time Token Arends 
can help the teacher to avoid talking domination and learners' silence (2014). Thus, it is appropriate to build up the students' involvement and bravery in language learning process.

Unfortunately, according to the teacher's explanation from interviewing are found that the most students at the first grade of science in MA AL-Bairuny still get difficulty in learning speaking when the teacher uses Time Token Arends method; and the students are still too shy to speak English because of lack of confidence and worrried about the mistakes. As Ur (1996) stated that there are some reasons influenced the student's reluctance to speak English such as: worried about making mistakes, fearful or criticism, or simply shy; nothing to say and no motivation to express themselves; low or uneven participation; and the influence of their mother tongue. Furthermore, sometimes some students may lose their words while they are speaking it.

Considering the students' problems in speaking English, the teacher needs a strategy that can overcome it. In accordance with the descriptions above, the researcher has conducted a study entitled "Teacher's Strategies to Overcome Students' Difficulties when Implementing Time Token Arends Method in Learning Speaking English" and show how the teacher overcome the students' difficulties at first grade of science in MA AL-Bairuny.

\section{REVIEW OF RELATED THEORY}

As Richard's said (2010) that speaking is the most important things in communicate, because since we were born, we were taught to speak before we know the writing and reading. And speaking is one of the four basic language skills that in a second or foreign language, has often been viewed as the most demanding of the four skills. Though the students of EFL get some problems in practicing their English, especially in speaking, some teachers have implemented the methods or strategies to overcome it. One of the methods is Time Token Arends. It suits to attract the students' participation in developing speaking skill and to motivate and activate the students to speak English.

Basically, for EFL is not easy to master an English speaking. In learning speaking, the students are usually faced by the problems during teaching learning process. Ur (1996) explained that there are some difficulties faced by the learners in speaking activities. These problems can be explained as follow:

\section{Inhibition}

Unlike reading, writing, and listening activities, speaking requires some real time exposure to an audience. Learners is often inhibited about trying to say things in a foreign language in the classroom, such as worried about making mistakes, fearful or criticism, or shy of their speech attracts.

\section{Nothing to say}

The learners have not idea to speak. Some learners get the difficulties in thinking of anything to say, they have no bravery to express their thinking.

\section{Un-event participant}

Only one participant can talk at a time if he or she is to be heard. In large group, this means that each one will have only very little time talk. This problem is compounded by tendency of some learners to dominate, while others speak very little or not at all.

\section{Mother tongue used}

In a number of classes, the learners share the same mother tongue. They may tend to use it because of some reasons. Firstly, it is easier. Secondly, it feels unnatural to speak to one to another one. Nevertheless, they are talking in small groups, it can be quite difficult to keep use the target language.,

To overcome those problems, the speaking activities have to use some strategies to improve students' awareness on it. In Lie (2004) there are five elements after applied Time Token Arends which increase the students' involvement in speaking learning process, according to Borich, 2004 cited in; Johnson \& Johnson (2000): 


\section{Interdependence}

Creating the effective working team, it needs to elaborate the duty by help each other in such a manner.

\section{Look in the face}

Looking the other face when feel nervous can build up the confidence. It makes positive energy interact with the student's bravery. The point from this synergy is esteem the difference, and to fill insufficiency.

\section{Responsibility}

By dividing the students in some group and giving them some tasks to solve can build student's own responsibility. They have self-awareness to take over their duty.

\section{Communications}

Communicate with other freely will make the students following the skill communication process. It will very useful in pushing the students to enrich speaking experience and to learn new vocabulary in.

\section{Evaluate}

Evaluating the teamwork process and product can cooperate effectively in developing student's speaking skill.

There are two previous studies that almost have same topic with the research. The first previous study was conducted by Asmiati (2010). Her research aimed to provide speaking skill of the $2^{\text {nd }}$ year students of SMA Negeri 1 Lilirilau Soppeng by using Time Token Arends method. The writer used purposive sampling technique and it consists of 30 students. Based on the findings, the writer concluded that the $2^{\text {nd }}$ year students of SMA Negeri 1 Lilirilau Soppeng could develop their speaking using Time Token Arends, and the students' interest in speaking English using Time Token Arends was positive. It means that, there was significant improvement of the students speaking ability and the students have positive interest toward the use of Time Token Arends method.

The second previous studies were conducted by Syukrilahanisa (2014). Her research purpose is teaching speaking by using Time Token Arends methodat the eleventh grade of SMA Wahid Hasyim Tersono, Batang in the Academic Year of 2015/2016 that the research was to find out the effectiveness of time token arends strategy to improving the learners' speaking ability. After observed the technique from teaching process using time token arends the environment of the students is good. It means that there was a significant difference in speaking skill improvement who are taught using Time Token Arends.

The research has difference focus from these two researchers. This research focused on describing the students' difficulties in learning speaking using Time Token Arends, and how does the teacher overcome the difficulties.

\section{METHOD}

The researcher used descriptive qualitative in this research. According to Moleong (2012), the descriptive qualitative is the data collected from words, images, and not numbers. Based on the description above, the researcher was functioned as interviewer and the researcher was functioned as an observer. So, by using descriptive qualitative method researcher just focus on describe the data that got from the teacher, and the research question clearly answered and described by the researcher. The design process was conducted by some steps. First, among students' difficulties in learning speaking English using Time Token Arends, and the second, how does the teacher overcome the difficulties. Based on those learning, the researcher took the data based on interview the teacher and observed the learning process in the class.

The subject of this research was the teacher who only teaches first grade of science at MA AL-Bairuny which there were 15 students within high and low level academically. Hence, the 
researcher selected two of low level and also two of high level students academically to represent the result of the research. Unfortunately, the researcher taught in this school, so the researcher knew the condition in this school. The material of this research was descriptive text. The researcher used secondary data from the teacher, because the teacher knew well about the students' condition in first grade science at this school.

There are two kinds of data in this research. They are: The first, students' difficulties in learning speaking English when implementing Time Token Arends, it used interview from the teacher. The second data, the teacher's strategies in overcoming the students' difficulties, it used interview from the teacher.

To collect the data, the researcher used interview. Interview was to get some information, the researcher conducting interview. In this study, the researcher collected the data by interviewing with the English teacher. She is Mrs. Atin of first grade science at MA AL-Bairuny. The researcher used notebook and recorder as the tool to collect the data. The researcher asked some questions related students' difficulties in speaking English when the teacher implementing Time Token Arends, and how the teacher overcome the students' difficulties, and any other questions that might help in completing the data.

The data for this study were collected through the following steps: First, asking the teacher and conveying the purpose of this research. Second, interviewing the teacher to know students' difficulties in speaking English when the teacher implementing Time Token Arends, and how does the teacher overcome the students' difficulties. Third. The researcher analyzed the data that tend to be answered the research problem.

After the data were collected from the teaching learning process for three days within different time schedule which was an hour thirty per day, and interviewed the teacher. Moreover, the researcher analyzed the data through some steps, which were: The first, describing the data, the researcher described the result of students' difficulties in speaking English when the teacher implementing Time Token Arends, and how does the teacher overcome the students' difficulties. The second, concluding the data, in this step, the researcher made a conclusion related to the students' difficulties in speaking English when the teacher implementing Time Token Arends, and how does the teacher overcome the students' difficulties.

\section{RESULTS}

Based on the data of interview, this category of the teacher strategies and the students' difficulties in learning speaking English was found in:

Table 1. The students' difficulties in "Inhibition", and "Look in the face" strategies.

\begin{tabular}{lll}
\hline No. & \multicolumn{1}{c}{ Students' Difficulties } & \multicolumn{1}{c}{ Teacher's Strategies } \\
\hline \multicolumn{1}{c}{ Inhibition: } & \multicolumn{1}{c}{ Look in the face } \\
\hline $\begin{array}{l}\text { Student 1: The student had } \\
\text { difficulty in starting to speak } \\
\text { because of being worried of making } \\
\text { mistakes. }\end{array}$ & $\begin{array}{l}\text { The teacher gave opportunity to the student to look at } \\
\text { other members' face in order to decrease his worry } \\
\text { and asked him to have discussion. }\end{array}$ \\
$\begin{array}{l}\text { Student 2: Student had difficulty in } \\
\text { answering the question. }\end{array}$ & $\begin{array}{l}\text { The teacher gave opportunity to the student to discuss } \\
\text { with his member to solve his problems of what he } \\
\text { did. }\end{array}$ \\
\hline $\begin{array}{l}\text { Student 4: Student felt nervous and } \\
\text { shy to speak in front of the class. }\end{array}$ & $\begin{array}{l}\text { The teacher asked the student to look at his friends' } \\
\text { face in his member to avoid nervousness. }\end{array}$ \\
\hline
\end{tabular}

Student 1 actually knew what to say, but he had difficulty in starting to speak. So that, when the teacher asked him, answered the question that had already provided by speaking, he felt nervous and worry to answer the question, It was proved from the teacher's information, that like 
he said "Emmm... sebentar Mom, saya masih bingung". Based on the difficulty, the teacher gave opportunity to the student to look at the other members' face in order to decrease his worried about making mistakes and asked him to have discussing. After that, the teacher asked student 1 discussed with his member for solving his difficulty in did his duty "If you have difficulty, you can have discussed with your friends, don't worry about making mistakes". So, with having interaction activity with another member, it could give all students to fill insufficiency all members, so it could make Student 1 decrease his worry. So, in sixty seconds "Mom I want to answer for identification" and the teacher said "Yes, please". So, Student 1 can answer for identification, that is "Tanjung Puting National Park is located in the Southwest of Central Kalimantan peninsula".

The second, in first coupons Student 2 had difficulty in answering the question that had already provided. From some of material about the structures, and language features of descriptive text that had described by the teacher, he was only able to answer about simple present, because the material that he understands, and he often learns about simple present. It's proved from the teacher's information, that like he said "Mom saya cari tentangsimple present saja ya...". So, when the teacher asked him to answer the question except simple present, he felt nervous, and worry about making mistakes to answer the question.

Based on the difficulty, the teacher gave opportunity to the student to discuss with his member to solve his problems of what he did. So, this interactive activity that to solve his problems in looking the answer gave all students to fill insufficiency all members. After that, in sixty seconds, he could find 2 simple presents, "Though the park is home to many animals, seeing orangutans is usually the visitors' main reason to visit the park" in second paragraphs. And "To see orangutans, we should go to Camp Leakey, which is located in the heart of Tanjung Puting National Park" in third paragraphs. Although, to answer the question he needed time more sixty second. However, the teacher knew that he is smart in the simple present, because from his daily work especially simple present, he always gets a good score, but for improving his speaking skill the teacher asked him always trying to speak English.

The third, in first coupons Student 4 felt nervous and shy to speak in front of the class. Because when he spoke in front of the class, certainly all students and teacher looked toward the student, so he felt nervous when he wanted to speak, and what is in his mind was lost. So that he asked to the teacher "Mom saya boleh menulis jawaban lembar jawaban saja?" and the teacher said that"No! Now times for speaking, and I'll help you in this section, so don't be worried". Based on the difficulties, Student 4, when he felt nervous and shy to speak in front of the class, the teacher asked the student to look at his friends' face in his member to avoid nervousness. So, the teacher asked him to answer the question in his sit and look at his friends' face in his member, because it can decrease his nervousness. From that, in sixty seconds, he could find for description in fifth paragraphs "In daylight, on your way to Camp Leakey, you can see trees filled with proboscis monkeys, monkeys that have an enormous snout which can only be found in Kalimantan". The teacher asked all students gave applause to this student to build his motivation to speak in front of his friends. 
Table 2. The students" difficulties in "Nothing to Say", and "Communication" strategies.

\begin{tabular}{lll}
\hline No. & \multicolumn{1}{c}{ Students' Difficulties } & \multicolumn{1}{c}{ Teacher's Strategies } \\
\hline \multicolumn{1}{c}{ Nothing to Say } & \multicolumn{1}{c}{ Communication } \\
\hline & $\begin{array}{l}\text { When the student was no idea to speak, } \\
\text { the teacher asked for the student to } \\
\text { communicate with others to exchange } \\
\text { mind in order to help him ready to speak. }\end{array}$ \\
\hline $\begin{array}{l}\text { Student 1: Student had no idea to speak. } \\
\text { Shat he wanted to speak. }\end{array}$ & $\begin{array}{l}\text { The teacher asked what his problem } \\
\text { were and tried to ask him to } \\
\text { communicate with others to make him } \\
\text { ready to speak. }\end{array}$ \\
\hline $\begin{array}{l}\text { Student 4: Student had no bravery } \\
\text { express their thought. }\end{array}$ & $\begin{array}{l}\text { The teacher asked the student to } \\
\text { communicate each other and listen very } \\
\text { carefully to their friends' opinion. }\end{array}$ \\
\hline
\end{tabular}

In this stage, the researcher was showed there were 3 students had difficulty in "Nothing to Say" they are: Student 1 had no idea to speak, so, when he has time twenty seconds more in first coupons, he asked to his members, but no communication each other because the other member just focused on their turn. Therefore, he asked to skip for the other members to answer and it also happened in second coupons. Based on the difficulties, the teacher asked for the student to communicate with others to exchange minds in order to help him ready to speak. And finally, after discussing with his member, Student 1 tried to answer language features from Tanjung Puting National Park text. For the simple present he just could find "Tanjung Puting National Park is an internationally famous ecotourism destination, and this is called a park", although to answer it Student 1 need time more than sixty seconds, the teacher still gave him appreciation for building his confidence.

The second, Student 2 got difficult to express what he wanted to speak. Actually, he could answer the question, but he difficulty to express what he wanted to speak, because he said that lack of vocabulary. So, in second coupons he tried to answer the structures, but he took too much time to think, so the time walk around 40 seconds for thought, so he just got 1 of description "It is a real jungle, which is home to the most interesting animal in the world: orangutans". Based on the difficulties, The teacher asked what his problem were and tried to ask him to communicate with others to make him ready to speak. So, when he felt difficulty to speak, the teacher asked him to communicate in did the duty with his member, and tried to listen each other opinion and their ability to phrase their opinion. And finally, in thirty seconds he can answer "Orangutans, which literally mean the man of the forest, are the largest arboreal animal on the planet" in the second paragraphs.

The third, Student 4 had no bravery to express his thought. The main reason student 4 had no bravery to express his thought is his lack of vocabulary, and he less practiced in learning speaking English. So, when the teacher asked him to speak, he was afraid about he talked is wrong. Based on the difficulties, the teacher asked the student to communicate each other and to listen very carefully to their friends' opinion. So, in this stage they tried to listen each other opinion for solving his difficulty. And finally, he tried to find language features, and its need more than forty seconds he just answers for noun phrase in third paragraphs "the rehabilitation process to their natural habitat". 
Table 3.The students" difficulties in "Un-event Participant", and "Interdependence" strategies.

\begin{tabular}{cll}
\hline No. & \multicolumn{1}{c}{ Students' Difficulties } & \multicolumn{1}{c}{ Teacher's Strategies } \\
\hline & \multicolumn{1}{c}{ Un-event Participant } & \multicolumn{1}{c}{ Interdependence } \\
\hline \multirow{3}{*}{$\begin{array}{l}\text { Student 1: Student took much time to } \\
\text { think, so he missed chance to speak. }\end{array}$} & $\begin{array}{l}\text { Teacher gave a golden coupon to } \\
\text { provide more time to the student to } \\
\text { discuss with his member of what they } \\
\text { had the solution to speak. }\end{array}$ \\
\hline $\begin{array}{l}\text { Student 2: Student skipped looking } \\
\text { for the answer, so he just has a little } \\
\text { participation. }\end{array}$ & $\begin{array}{l}\text { Teacher didn't let the student for skip } \\
\text { his turn, and asked the student to ask for } \\
\text { help with his member }\end{array}$ \\
\hline $\begin{array}{l}\text { Student 4: He just had little } \\
\text { participation, because student 3 was } \\
\text { too dominate in speaking. }\end{array}$ & $\begin{array}{l}\text { Teacher asked student 3 to let student 4 } \\
\text { to speak in order to have same chance } \\
\text { in did the duty, so, no talking } \\
\text { domination in this group. }\end{array}$ \\
\hline
\end{tabular}

In this stage, the researcher was showed there were 3 students had difficulty in "Un-event Participant" they are: The first, in last coupons, Student 1took much time to think, so he missed a chance to speak. When the teacher asked him to find the answer, he said to the teacher that he still tried to comprehend the question, so he took too much time to think, and he missed the time and he just had little participation.

Based on the difficulties, the teacher gave a golden coupon to provide more time for the student to discuss with his member of what they had the solution to speak. It's for creating effective working team by giving the instructions that he should discuss with his member in doing the assignment. The teacher gave a roll of pieces papers that contained of "Borobudur Temple" (relating to text that ever given by the teacher), and the teacher asked Student 1 to talk about Borobudur Temple with his own word using English. Found the meaning of the sentence in English. Around 2 minutes discussed with his member he told "Borobudur temple is a bigger temple in Indonesia. It's located in Magelang, Central Java. There are many stupas there, that our hand can touch the stupa, our dream will come true". So that every group member has to finish its own duty so that others can reach their target.

The second, in last coupons, the teacher asked Student 2 found 4 noun phrases, but he said "Mom please, 3 saja ya Mom?", and the teacher still asked him to try to find 4 noun phrases. Around fifty seconds he found in first paragraphs "amazing nature", and "interesting animal", but when student 2 still have time ten seconds more to find another noun phrase, he chose to stop looking for the answer. The reason why student 2 chose for skipping his turn is felt nervous to speak. And when he wanted to answer the question that he could, but the question had already answered by another member. So, he chose to skip looked for the answer and he just had little participation. Based on the difficulties, the teacher didn't let the student for skipping his turn, and asked the student to ask for help with his member. Because student 2 cannot answer for language features or structures, the teacher asked him to retell about "Kebon Ratu" that had ever given by the teacher. In order to give student 2 opportunity to speak. Around 2 minutes the student retell "Kebon Ratu is a park that located in Keplaksari, Jombang. It is very large park, and many people come here to take picture and have fun together. There are 2 planes there.". So that every group member has to finish its own duty so that others can reach their target.

The third, Student 4 just have only very little time to speak because another member was too dominant in speaking. When student 4 had difficulty answering the question, it should for other member to help him to solve the difficulty in answering the question. But student 3 didn't help him, but he immediately answers the question that he couldn't answer without discussing it with them. So, student 3 talked to dominate, and also Student 4 didn't brave share his thought. 
So, in last coupons, he just found two adjectives by himself, although he needs more sixty minutes to answer, he found "amazing (in first paragraph), famous (in the third paragraph." Because he still has time fifteen seconds, the teacher asked him to find two more again, he tried to discuss with his member, but he took too much time to think, so he missed a chance to answer again. Based on the difficulties, the teacher asked student 3 to let student 4 to speak by helping him to solve his difficulties, in order to have the same chance in did the duty, so, no talking domination in this group. So, when the teacher asked student 4 retell about "Prambanan Temple" that have ever given by the teacher, student 3 should help him to speak with his own word. Around 2 minute student 4 retell "Prambanan Temple is one of Hindu Temple in Indonesia. It is located on Yogyakarta, Central Java. Prambanan Temple built on dynasty Sanjaya.". So that every group member have to finish its own duty so that others can reach their target. So, from this stage no domination in this group.

Table 4 The students' difficulties in "Mother Tongue Used", and "Responsibility" strategies.

\begin{tabular}{|c|c|c|}
\hline No. & Students' Difficulties & Teacher's Strategies \\
\hline & Mother Tongue Used & Responsibility \\
\hline 4 & $\begin{array}{l}\text { Student } 1,2,3,4: \text { Students felt } \\
\text { easier for communication each } \\
\text { other using Java Language, so } \\
\text { they ignored the teacher's } \\
\text { instruction for speaking English. }\end{array}$ & $\begin{array}{l}\text { Teacher gave punishment to the student who } \\
\text { ignores the instruction to speak English by } \\
\text { memorizing } 3 \text { new vocabularies, in order to } \\
\text { enrich their vocabulary and help them easier } \\
\text { to speak. And teacher gave understanding } \\
\text { about the important of speaking English, so } \\
\text { teacher still asked them always trying speak } \\
\text { English. }\end{array}$ \\
\hline
\end{tabular}

All member in this group (Student 1,2,3,4) felt easier for communication each other using Java Language, so they ignored the teacher's instruction in speaking English. It's proved when the teacher asked all students in this group to solve their difficulties in did their duty or discuss each other using English, but they still discussed with his members using Javanese language, although many times the teacher warned them "Speak English please..!!!", and they still ignore the warned from the teacher. Based on the difficulties, the teacher gave punishment to the student who ignores the instruction to speak English by memorizing 3 new vocabularies, in order to enrich their vocabulary and help them easier to speak. And the teacher gave understanding about the importance of speaking English, so teacher still asked them always trying to speak English.

The last strategy for all students is evaluation. At the end of learning activity teacher made a schedule for this group to evaluate their teamwork process. The teacher informed their difficulties to all members in this group that are for inhibition: Student 1 had difficulty in starting to speak because of being worried of making mistakes, Student 2 had difficulty in answering the question from the teacher, and Student 4 felt nervous and shy to speak in front of the class. For nothing to say: Student 1 had no idea to speak, Student 2 got difficulty when he wanted to express what he wanted to speak, and Student 4 had no bravery to express their thoughts. For Un-Event Participant: Student 1 took much time to think, so he missed the chance to speak, Student 2 skipped looking for the answer, so he just has a little participation, and student 4 just had little participation, because another member was too dominant in speaking. And for Mother Tongue Used: Students felt easier for communication each other using Java Language, so they ignored the teacher's instruction in speaking English. And the teacher informed their result of their job that they can do anything if they want to try. And it helped from the stimulus that have given by the teacher and their friends, so, they could try to speak English and did the duty, and with this they can cooperate effectively. This strategy, in order to inform the students about their lack (students can correct their lack), inform their ability, and gave them suggestion and motivation. 


\section{DISCUSSION}

According to the research of Asmiati (2010) aimed to provide speaking skill of the $2^{\text {nd }}$ year students of SMA Negeri 1 Lilirilau Soppeng by using Time Token Arends method. Based on the findings, the writer concluded that the $2^{\text {nd }}$ year students of SMA Negeri 1 Lilirilau Soppeng could develop their speaking using Time Token Arends, and the students' interest in speaking English using Time Token Arends was positive. It means that, there was significant improvement of the students speaking ability and the students have positive interest toward the use of Time Token Arends method.

The second previous studies were conducted by Safitri (2015). Teaching speaking by using Time Token Arends method at the eleventh grade of SMA Wahid Hasyim Tersono, Batang in the Academic Year of 2015/2016 that the research was to find out the effectiveness of time token arends strategy to improving the learners' speaking ability. After observed the technique from teaching process using time token arends the environment of the students is good. It means that there was a significant difference in speaking skill improvement who are taught using Time Token Arends.

So, from the previuos studies, in this research presented the students' difficulties in learning speaking English using Time Token Arends for subject descriptive text. The data of this study were descriptive text for first grade students of senior high school in the first semester. Then, the instrument used in collecting the data in this study were interviewed the teacher about the students' difficulties faced in learning speaking English and observed the learning process when the teacher used Time Token Arends. At the meeting, teacher was asked to the students answer the assignment about descriptive text by speaking. This was proposed to explain the students' difficulties in learning speaking English for subject descriptive text using Time Token Arends. The difficulties are according to Ur (1996, p: 121) explained that there are some difficulties faced by the learners in speaking activities, that are: Inhibitation, Nothing to Say, Un-event Participation, Mother Tongue Used. And how the teacher overcame the difficulties by using five elements basic models of cooperative learning based on Borich, 2004 cited in; Johnson \& Johnson (1999) that are interdependence, look in the face, responsibility, communications, and evaluate.

Table 5. The Result of Students' Difficulties in Learning Speaking English

\begin{tabular}{ccc}
\hline No. & Students' Difficulties & Sum of Students \\
\hline 1 & Inhibition & 3 \\
\hline 2 & Nothing to Say & 3 \\
\hline 3 & Un-event Participant & 3 \\
\hline 4 & Mother Tongue Used & 4 \\
\hline
\end{tabular}

There were 4 students' works that were analyzed. Based on the fact the difficulties were made by students during their try to answer the assignment by speaking. From the data presented in the general result, it was found that 3 students had difficulties in "Inhibitation", such as Student 1: The student had difficulty in starting to speak because of being worried about making mistakes.

Student 2: Student had difficulty in answering the question from the teacher. And Student 4: Student felt nervous and shy to speak in front of the class. And the difficulty was found that 3 students had difficulties in "Nothing to Say", such as: Student 1: Student had no idea to speak. Student 2: Student got difficult to express what he wanted to speak. Student 4: Student had no bravery to express their thoughts. And from the data was found that 3 students had difficulty in "Un-event Participant", such as: Student 1: Student took much time to think, so he missed a chance to speak. Student 2: Student skipped looking for the answer, so he just has a little 
participation. And Student 4: he just had little participation, because student 3 was to dominate in speaking. And the last, the data was found 4 students had difficulties in "Mother Tongue Used", such as: Student 1,2,3,4: All students felt easier for communication each other using Java Language, so they ignored the teacher's instruction in speaking English.

Table 6. Teacher Strategies to Overcome The Students' Difficulties

\begin{tabular}{ccc}
\hline No. & Teacher's Strategies & Sum of Students \\
\hline 1 & Look in the face & 3 \\
\hline 2 & Communication & 3 \\
\hline 3 & Interdependence & 3 \\
\hline 4 & Responsibility & 4 \\
\hline 5 & Evaluation & 4 \\
\hline
\end{tabular}

From the data presented in the general result, it was found that the teacher had strategies to overcome the students' difficulties in "Inhibition" by using "Look in the face" strategies, such as: Student 1: The teacher gave opportunity to the student to look at the other members' face in order to decrease his worry and asked him to have discussing. Student 2 : The teacher gave opportunity to the student to discuss with his member to solve his problems of what he did. And Student 4: The teacher asked the student to look at his friends' face in his member to avoid nervousness.

And from the data was found from the teacher's strategies for overcome the students' difficulties in "Nothing to Say" by using "Communication" such as: Student 1: When the student was no idea to speak, the teacher asked for the student to communicate with others to exchange minds in order to help him ready to speak. Student 2: The teacher asked what his problem were and tried to ask him to communicate with others to make him ready to speak. And Student 4: The teacher asked the student to communicate each other and listen very carefully to their friends' opinion.

The data were found from the teacher's strategies to overcome the students' difficulties in "Un-event Participant" by using “Interdependence" such as: Student 1: Teacher gave a golden coupons to provide more time to the student to discuss with his member of what they had the solution to speak. Student 2: Teacher didn't let the student for skipping his turn, and asked the student to ask for help with his member. And Student 4: Teacher asked student 3 to let student 4 to speak in order to have the same chance in did the duty, so, no talking domination in this group.

The data was found from the teacher's strategies for overcome the students' difficulties in "Mother Tongue Used" by using "Responsibility" such as: Teacher gave punishment to the student who ignores the instruction to speak English by memorizing 3 new vocabularies, in order to enrich their vocabulary and help them easier to speak. And the teacher gave understanding about the importance of speaking English, so teacher still asked them always trying speak English.

The last strategy for all students is evaluation. In the end of learning activity teacher made a schedule for this group to evaluate their teamwork process (they less in communication each other especially using English, they worried about making mistakes, felt nervous, so they could not release their opinion freely), and the result of their job (with the stimulus from the teacher and their friends, they could try to speak English and did the duty), so by this they could cooperate effectively. This strategy was able to inform the students about their lack (students can correct their lack), informed their ability, and gave them suggestion and motivation.

\section{CONCLUSION}

By using Time Token Arends some students have difficulty in inhibitation, nothing to say, unevent participant, and mother tongue used. However, to overcome the students' difficulties 
teacher use strategies from five basic elements in cooperative learning, that are; look in the face, responsibility, communication, interdependence, and evaluation. Especially after teacher has applyed five basic elements model of cooperative learning students more active to try speaking English. They are able to deliver their thinking freely.

\section{REFERENCES}

Asmiati, A. (2010). Using Time Token Arends to Improve Speaking Ability to The Second Year Students of SMA Negeri 1 Lilirilau Soppeng. Unpublished thesis. Alauddin State Islamic University.

Brown, H. D. (2001). Principle of Language Learning and Teaching. Englewood Chiffs. Prentice Hall.

Jhonson \& Jhonson (2004). Teaching Skills for Cooperation in the Classroom. Journal of Education, Recreation, \& Dance, 27-31.

Johnson, D.W., Johnson, R.T., \& Stanne, M.E. (2000). Cooperative Learning Methods: A metaanalysis. University of Minnesota, Minneapolis: Cooperative Learning Center. http://www.cooperation.org/pages/cl-methods.html

Lie, A. (2004). Cooperative Learning Method. PT Remaja Rosda Karya.

Moelong, L. (2004). Metode Penelitian Kualitatif. PT Remaja Rosda Karya.

Richards (2008). Learning Speaking Skill for Good Communication. Journal of English and Education, 26-28.

Safitri, A. (2015). Teaching speaking by using Time Token Arends method at the eleventh grade of SMA Wahid Hasyim Tersono, Batang in the Academic Year of 2015/2016. Undergraduate (S1) thesis, Universitas Islam Negeri Walisongo Semarang.

Sukmayati. (2014). Improving speaking ability of the eleventh year students of SMA laboratorium Unsyiah Banda Aceh by using time token arends technique. 36-44. ISSN 2355-004X.

Syukrilahanisa, F. (2014). The Effectiveness of Time Token Arends in Teaching Speaking (Experimental Study at the Eighth Grade Students of SMP Diponegoro 8 Rawalo Banyumas in the AcademicYear 20013/2014). Journal of Education Program of Muhammadiyah University of Purwokerto http://fkip.ump.ac.id/index.php/artikelskripsi/viewdownload/7-pendidikan-bahasa-inggris/33.

Ur (1996). English Speaking Difficulty faced by Students in Learning Speaking English. Journal of Physical Education, Recreation, \& Dance, 121. 